\title{
MENINGKATKAN KOMPETENSI PENGELOLAAN PEMBELAJARAN GURU BAHASA INGGRIS SEKOLAH DASAR MELALUI KEGIATAN KELOMPOK KERJA GURU
}

\author{
Zulhermindra \\ Program Studi Tadris Bahasa Inggris, Jurusan Tarbiyah STAIN Batusangkar \\ Korespondensi: Jl. Sudirman, No.137 Kubu Rajo, Lima Kaum, Batusangkar, Sumatera Barat \\ E-mail: zulhermindra@yahoo.com
}

\begin{abstract}
The teaching of English at elementary school level is believed to give promising contribution since it can improve students' language proficiency at early stages. However, teachers' professional competency is suspected as one of potential problems due to the facts that some of them are not really prepared to teach at this level. Even most of the teachers are not English teaching background. Realizing the phenomena, continuous training and knowledge upgrading programs should be of prior concern. This article is therefore intended to share some ideas how to improve elementary English teachers' professional competency, especially in designing syllabus and develepoing lesson plan by considering the nature ofvelepoing lesson plan by considering the nature of young learners and the principles of teaching them as well.
\end{abstract}

Kata kunci: kompetensi, pengelolaan pembelajaran, guru, bahasa Inggris, KKG

\section{PENDAHULUAN}

M enteri Pendidikan dan Kebudayaan melalui Surat Keputusannya No. 0487/4/1992 menegaskan bahwa Bahasa Inggris dapat diajarkan mulai kelas 4 pada sekolah dasar sebagai kurikulum muatan lokal. Cameron (2001: 16-17) menulis bahwa ada banyak keuntungan yang dapat diperoleh apabila bahasa asing (misalnya Bahasa Inggris) diajarkan pada tahuntahun awal, terutama untuk keterampilan menyimak seperti pronounciation jangka panjang dalam konteks yang realistis. Pufahl dan kawan-kawan (2001) berdasarkan hasil penelitian mereka "What We can Learn from Foreign Language Teaching in Other Countries", menegaskan banyak responden yang me- nemukan bahwa memulai pembelajaran bahasa asing lebih awal meningkatkan pencapaian profisiensi bahasa pada level-level yang tinggi. Ur (2000:286288) mengemukakan beberapa asumsi tersebut sebagai berikut: (1) anak-anak belajar lebih cepat dan lebih baik dari orang dewasa, (2) pembelajaran bahasa asing di sekolah sebaiknya dimulai lebih awal, (3) anak-anak belajar bahasa dengan cara yang sama, (4) orang dewasa memiliki rentang konsentrasi yang lebih lama dibanding anak-anak, dan (5) anakanak lebih mudah tertarik dan termotivasi ketimbang orang dewasa.

Namun beberapa permasalahan masih banyak ditemukan dalam pembelajaran bahasa Inggris untuk anakanak di Indonesia. Kasihani (2001: 233234) menenggarai bahwa sebahagian 
besar guru-guru yang mengajar bahasa Inggris di SD adalah mereka yang belum mendapatkan pe-latihan khusus tentang pengajaran bahasa Inggris tersebut. Akibatnya, mereka yang mengajar Bahasa Inggris di SD memilliki kemampuan mengajar bahasa Inggris yang sangat terbatas karena memang tidak memiliki latar belakang ilmu yang memadai, terutama yang berkitan dengan metodologi pengajaran.

Sejalan dengan temuan di atas, Rosenbusch (2000) menekankan bahwa ada beberapa faktor lainnya yang perlu diantisipasi dalam perencanaan pembelajaran bahasa asing di tingkat pendidikan dasar. Diantara faktor-faktor tersebut adalah: (1) kurangnya jumlah guru yang memiliki keterampilan berbahasa yang memadai serta kualifikasi dalam mengajarkan bahasa asing kepada anak-anak, (2) metodologi pengajaran yang kurang/tidak tepat untuk anak-anak, (3) materi pembelajaran yang tidak cukup dan tidak memadai, dan (4) kurangnya prosedur evaluasi terhadap siswa, guru dan program itu sendiri.

Berdasarkan informasi yang diperoleh dari Koordinator Kelompok Kerja Guru (KKG) Bahasa Inggris diperoleh gambaran bahwa dari 19 orang tenaga pengajar bahasa Inggris di 27 SD di kecamatan ini ternyata mereka adalah guru honorer dan guru kelas. Bahkan $30 \%$ dari mereka tidak memiliki kualifikasi pengajar bahasa Inggris. Ini belum termasuk tenaga pengajar yang tidak berlatar belakang Pendidikan Bahasa Inggris. Kalaupun ada kesempatan untuk mengikuti pelatihan atau workshop dalam rangka peningkatan wawasan dan keterampilan mengajar guru bahasa Inggris untuk SD, maka sekolah lebih memberikan prioritas kepada guru tetap (PNS) yang umumnya guru kelas dan tidak berlatar belakang pendidikan bahasa Inggris.

Di samping itu, belum adanya pengawas mata pelajaran bahasa Inggris untuk tingkatan SD semakin membuat pembelajaran bahasa Inggris di SD seperti jalan sendiri-sendiri. Tidak mengherankan jika pembelajaran bahasa Inggrispun berlangsung sesuai dengan pemahaman masing-masing guru. Kondisi-kondisi di atas ini tentu saja sangat berdampak kepada pencapaian kualitas pembelajaran dan pencapaian kompetensi yang diharapkan.

Informasi di atas juga menegaskan bahwa selama ini pembelajaran Bahasa Inggris di sekolah dasar belum lagi terkelola secara profesional. Ini dapat dilihat dari kompetensi guru yang mengajar belum lagi memenuhi persyaratan yang diinginkan oleh Lampiran Peraturan Menteri Pendidikan Nasional Nomor 16 Tahun 2007 tentang Standar Kualifikasi Akademik dan Kompetensi Guru.

Berdasarkan hasil pengamatan dan studi pendahuluan di lapangan, ditemukan beberapa permasalahan yang sangat potensial dalam pengajaran bahasa Inggris di sekolah dasar,: (1) sebagian besar guru yang mengajar bahasa Inggris di SD tidak memiliki kurikulum dan hanya berpedoman kepada topik yang ada dalam buku paket dan intuisi guru tersebut, (2) keterampilan dasar berbahasa Inggris sebagian besar guru bahasa Inggris di SD masih rendah, (3) sebagian dari guru tersebut tidak berasal dari LPTK sehingga pengetahuan tentang psikologi pembelajaran bahasa asing bagi anak-anak dan metodologi pengajaran bahasa Inggris tidak dimiliki, (4) hampir seluruh guru yang mengajar bahasa Inggris di SD tidak melalui pelatihan khusus pembelajaran bahasa Inggris untuk siswa SD.

Penelitian ini fokuskan untuk memperoleh gambaran apakah kegiatan Kelompok Kerja Guru (KKG) dapat meningkatkan kompetensi pengelolaan pembelajaran guru bahasa Inggris di sekolah dasar di kecamatan Lima Kaum kabupaten Tanah Datar dalam menyu- 
sun rencana pembelajaran, khususnya dalam menyusun silabus dan rencana pelaksanaan pembelajaran (RPP).

\section{KERANGKA TEORI}

\section{Pembelajaran Bahasa Asing pada Anak-anak}

Cameron (2001) mengemukakan bahwa anak-anak memiliki potensi yang luar biasa untuk dapat menguasai bahasa tertentu dan mereka memiliki tingkat penguasaan diluar yang kita bayangkan. Cameron lebih lanjut mengemukakan adalah anggapan yang salah kalau ada yang berpendapat bahwa anak-anak hanya bisa menguasai bahasa yang sederhana seperti berhitung menyebutkan warna, bemyanyi, dan percakapan sederhana. Mereka memiliki potensi yang jauh lebih besar

Dalam kaitannya dengan hakikat pembelajaran bahasa Inggris untuk anakanak, Harmer (2002) menegaskan bagaimana anak-anak belajar bahasa asing berbeda dengan orang dewasa. Menurutnya, beberapa karakteristik pembelajaran pada anak-anak tersebut adalah: 1) Siswa merespon makna bahkan jika mereka tidak mamahami kata-kata yang diucapkan, 2) Pemahaman mereka tidak hanya berasal dari penjelasan, tetapi juga dari apa yang mereka lihat atau dengar dan yang lebih penting jika mereka memperoleh kesempatan untuk menyentuh apa yang sedang mereka pelajari, 3) memiliki antusiasme dan perasaan ingin tahu yang tinggi, 4) membutuhkan perhatian individual dan pengakuan dari guru, 5) menyukai topiktopik yang terkait dengan kehidupan dan lingkungan mereka, 6) memiliki rentang perhatian yang terbatas terutama jika pembelajaran tidak menarik minat mereka.

Dalam kaitannya dengan pembelajaran bahasa pada anak-anak, Stocker (2007) memberikan tip bagaimana mengajarkan bahasa asing kepada anakanak, antara lain: 1) libatkan siswa dalam kegiatan yang bersifat kekinian (involve students in hands-on activities)., 2) hindari berbicara dalam waktu yang lama (avoid talking for long periods of time), 3) anak-anak belajar dengan berinteraksi dengan anak lainnya dan dengan guru (children learn by interacting with each other and with the teacher), 4) me-review materi secara berulang-ulang (review, review, review), 5) motivasi siswa mengoreksi kesalahan mereka sendiri dan orang lain (encourage students to correct themselves and other students), 6) berdayakan apa yang telah dipelajari dalam konteks yang berbeda (use what is learned in different contexts).

\section{Kompetensi Pengelolaan Pembe- lajaran}

Kompetensi, menurut Standar Kompetensi Guru, Bagian Komponen Pengelolaan Pembelajaran Dan Wawasan Kependidikan dan Komponen Pengembangan Profesi (2010), diartikan sebagai pengetahuan, keterampilan, dan nilai-nilai dasar yang direfleksikan dalam kebiasaan berpikir dan bertindak. Arti lain dari kompetensi adalah spesifikasi dari pengetahuan, keterampilan, dan sikap yang dimiliki seseorang serta penerapannya di dalam pekerjaan, sesuai dengan standar kinerja yang dibutuhkan oleh lapangan.

Dengan demikian, kompetensi yang dimiliki oleh setiap guru akan menunjukkan kualitas guru yang sebenarnya. Kompetensi tersebut akan terwujud dalam bentuk penguasaan pengetahuan, keterampilan maupun sikap profesional dalam menjalankan fungsi sebagai guru.

Standar Kompetensi Guru meliputi tiga komponen yaitu: (1) Komponen kompetensi pengelolaan pembelajaran dan wawasan kependidikan; (2) Komponen kompetensi akademik/vokasional 
sesuai materi pembelajaran; (3) Pengembangan profesi. Masing-masing komponen kompetensi mencakup seperangkat kompetensi. Selain ketiga komponen kompetensi tersebut, guru sebagai pribadi yang utuh harus juga memiliki sikap dan kepribadian yang positip dimana sikap dan kepribadian tersebut senantiasa melingkupi dan melekat pada setiap komponen kompetensi yang menunjang profesi guru.

Telah dinyatakan bahwa Standar Kompetensi Guru meliputi 3 (tiga) komponen kompetensi dan masingmasing komponen kompetensi terdiri atas beberapa unit kompetensi. Adapun Standar Kompetensi Guru yaitu: (1) Komponen kompetensi pengelolaan pembelajaran dan wawasan kependidikan; (2) Komponen kompetensi akademik/vokasional sesuai materi pembelajaran; (3) Pengembangan profesi.

Adapun Komponen Kompetensi Pengelolaan Pembelajaran adalah sebagai berikut:

1) Menyusun Rencana Pembelajaran, dengan indikator sebagai berikut: a) Mendeskripsikan tujuan pembelajaran, b) Menentukan materi sesuai dengan kompetensi yang telah ditentukan, c) Mengorganisasikan materi berdasarkan urutan dan kelompok, d) Mengalokasikan waktu, e) Menentukan metode pembelajaran yang sesuai, f) Merancang prosedur pembelajaran, g) Menentukan media pembelajaran/peralatan praktikum (dan bahan) yang akan digunakan, h) Menentukan sumber belajar yang sesuai (berupa buku, modul, program komputer dan sejenisnya), i) Menentukan teknik penilaian yang sesuai.

2) Melaksanakan Pembelajaran, dengan indikator sebagai berikut: a) Membuka pelajaran dengan metode yang sesuai, b) Menyajikan materi pelajaran secara sistematis, c) Menerapkan metode dan prosedur pembelajaran yang telah ditentukan, d) Mengatur kegiatan siswa di kelas, e) Menggunakan media pembelajaran/peralatan praktikum (dan bahan) yang telah ditentukan, f) Menggunakan sumber belajar yang telah dipilih (berupa buku, modul, program komputer dan sejenisnya), g) Memotivasi siswa dengan berbagai cara yang positif, h) Melakukan interaksi dengan siswa menggunakan bahasa yang komunikatif, i) Memberikan pertanyaan dan umpan balik, untuk mengetahui dan memperkuat penerimaan siswa dalam proses pembelajaran, j) Menyimpulkan pembelajaran, k) Menggunakan waktu secara efektif dan efisien.

3) Menilai prestasi belajar, dengan indikator sebagai berikut: a) Menyusun soal/perangkat penilaian sesuai dengan indikator/kriteria unjuk kerja yang telah ditentukan, b) Melaksanakan penilaian, c) Memeriksa jawaban/memberikan skor tes hasil belajar berdasarkan indikator/kriteria unjuk kerja yang telah ditentukan, d) Menilai hasil belajar berdasarkan kriteria penilaian yang telah ditentukan, e) Mengolah hasil penilaian, f) Menganalisis hasil penilaian (berdasarkan tingkat kesukaran, daya pembeda, validitas dan reliabilitas), g) Menyimpulkan hasil penilaian secara jelas dan logis (misalnya: interpretasi kecenderungan hasil penilaian, tingkat pencapaian siswa, dll), h) Menyusun laporan hasil penilaian, i) Memperbaiki soal/perangkat penilaian.

4) Melaksanakan tindak lanjut hasil penilaian prestasi belajar peserta didik, dengan indikator sebagai berikut: a) Mengidentifikasi kebutuhan tindak lanjut hasil penilaian, b) Menyusun program tindak lanjut hasil penilaian, c) Melaksanakan tindak lanjut, d) Mengevaluasi hasil tindak lanjut hasil penilaian, e) 
Menganalisis hasil evaluasi program tindak lanjut hasil penilaian.

Secara rinci, BNSP menegaskan bahwa perencanaan proses pembelajaran meliputi silabus dan rencana pelaksanaan pembelajaran (RPP) yang memuat identitas mata pelajaran, standar kompetensi (SK), kompetensi dasar (KD), indikator pencapaian kompetensi, tujuan pembelajaran, materi ajar, alokasi waktu, metode pembelajaran, kegiatan pembelajaran, penilaian hasil belajar, dan sumber belajar.

Silabus sebagai acuan pengembangan RPP memuat identitas mata pelajaran atau tema pelajaran, $\mathrm{SK}, \mathrm{KD}$, materi pembelajaran, kegiatan pembelajaran, indikator pencapaian kompetensi, penilaian, alokasi waktu, dan sumber belajar. Silabus dikembangkan oleh satuan pendidikan berdasarkan Standar Isi (SI) dan Standar Kompetensi Lulusan (SKL), serta panduan penyusunan Kurikulum Tingkat Satuan Pendidikan (KTSP). Dalam pelaksanaannya, pengembangan silabus dapat dilakukan oleh para guru secara mandiri atau berkelompok dalam sebuah sekolah/ madrasah atau beberapa sekolah, kelompok Musyawarah Guru Mata Pelajaran (MGMP) atau Pusat Kegiatan Guru (PKG), dan Dinas Pendidikan. Pengembangan silabus disusun di bawah supervisi dinas kabupaten/kota yang bertanggung jawab di bidang pendidikan untuk SD dan SMP, dan dinas provinsi yang bertanggung jawab di bidang pendidikan untuk SMA dan SMK, serta departemen yang menangani urusan pemerintahan di bidang agama untuk MI, MTs, MA, dan MAK.

Rencana Pelaksanaan Pembelajaran (RPP) dijabarkan dari silabus untuk mengarahkan kegiatan belajar peserta didik dalam upaya mencapai KD. Setiap guru pada satuan pendidikan berkewajiban menyusun RPP secara lengkap dan sistematis agar pembelajaran berlangsung secara interaktif, inspiratif, menyenangkan, menantang, memotivasi peserta didik untuk berpartisipasi aktif, serta memberikan ruang yang cukup bagi prakarsa, kreativitas, dan kemandirian sesuai dengan bakat, minat, dan perkembangan fisik serta psikologis peserta didik. RPP disusun untuk setiap KD yang dapat dilaksanakan dalam satu kali pertemuan atau lebih. Guru merancang penggalan RPP untuk setiap pertemuan yang disesuaikan dengan penjadwalan di satuan pendidikan. Adapun Komponen RPP adalah:

1. Identitas mata pelajaran

Identitas mata pelajaran, meliputi: satuan pendidikan, kelas, semester, program/program keahlian, mata pelajaran atau tema pelajaran, jumlah pertemuan.

2. Standar kompetensi

Standar kompetensi merupakan kualifikasi kemampuan minimal peserta didik yang menggambarkan penguasaan pengetahuan, sikap, dan keterampilan yang diharapkan dicapai pada setiap kelas dan/atau semester pada suatu mata pelajaran.

3. Kompetensi dasar

Kompetensi dasar adalah sejumlah kemampuan yang harus dikuasai peserta didik dalam mata pelajaran tertentu sebagai rujukan penyusunan indikator kompetensi dalam suatu pelajaran.

4. Indikator pencapaian kompetensi Indikator kompetensi adalah perilaku yang dapat diukur dan/atau di observasi untuk menunjukkan ketercapaian kompetensi dasar tertentu yang menjadi acuan penilaian mata pelajaran. Indikator pencapai-an kompetensi dirumuskan dengan menggunakan kata kerja operasional yang dapat diamati dan diukur, yang mencakup pengetahuan, sikap, dan keterampilan.

5. Tujuan pembelajaran

Tujuan pembelajaran menggambarkan proses dan hasil belajar yang 
diharapkan dicapai oleh peserta didik sesuai dengan kompetensi dasar.

6. Materi ajar

Materi ajar memuat fakta, konsep, prinsip, dan prosedur yang relevan, dan ditulis dalam bentuk butir-butir sesuai dengan rumusan indikator pencapaian kompetensi.

7. Alokasi waktu

Alokasi waktu ditentukan sesuai dengan keperluan untuk pencapaian KD dan beban belajar.

8. Metode pembelajaran

Metode pembelajaran digunakan oleh guru untuk mewujudkan suasana belajar dan proses pembelajaran agar peserta didik mencapai kompetensi dasar atau seperangkat indikator yang telah ditetapkan. Pemilihan metode pembelajaran disesuaikan dengan situasi dan kondisi peserta didik, serta karakteristik dari setiap indikator dan kompetensi yang hendak dicapai pada setiap mata pelajaran. Pendekatan pembelajaran tematik digunakan untuk peserta didik kelas 1 sampai kelas 3 SD/M I.

9. Kegiatan pembelajaran

a. Pendahuluan

Pendahuluan merupakan kegiatan awal dalam suatu pertemuan pembelajaran yang ditujukan untuk membangkitkan motivasi dan memfokuskan perhatian peserta didik untuk berpartisipasi aktif dalam proses pembelajaran.

b. Inti

Kegiatan inti merupakan proses pembelajaran untuk mencapai KD. Kegiatan pembelajaran dilakukan secara interaktif, inspiratif, menyenangkan, menantang, memotivasi peserta didik untuk berpartisipasi aktif, serta memberikan ruang yang cukup bagi prakarsa, kreativitas, dan kemandirian sesuai dengan bakat, minat, dan perkembangan fisik serta psikologis peserta didik. Kegiatan ini dilakukan secara sistematis dan sistemik melalui proses.eksplorasi, elaborasi, dan konfirmasi.

c. Penutup

Penutup merupakan kegiatan yang dilakukan untuk mengakhiri aktivitas pembelajaran yang dapat dilakukan dalam bentuk rangkuman atau kesimpulan, penilaian dan refleksi, umpan balik, dan tindaklanjut.

10. Penilaian hasil belajar

Prosedur dan instrumen penilaian proses dan hasil belajar disesuaikan dengan indikator pencapaian kompetensi dan mengacu kepada Standar Penilaian.

11. Sumber belajar

Penentuan sumber belajar didasarkan pada standar kompetensi dan kompetensi dasar, serta materi ajar, kegiatan pembelajaran, dan indikator pencapaian kompetensi.

\section{Kompetensi Guru Bahasa Inggris untuk Sekolah Dasar}

Lampiran Peraturan Menteri Pendidikan Nasional Nomor 16 Tahun 2007 tentang Standar Kualifikasi Akademik dan Kompetensi Guru berkaitan dengan Kompetensi Guru Mata Pelajaran Bahasa Asing, khususnya Kompetensi Guru Bahasa Inggris pada SD/MI sebagaimana halnya dengan SMP/MTs, dan SMA/MA, SMK/MAK menegaskan bahwa seorang guru bahasa Inggris harus: 1) memiliki pengetahuan tentang berbagai aspek kebahasaan dalam bahasa Inggris (linguistik, wacana, sosiolinguistik, dan strategis) dan 2) Menguasai bahasa Inggris lisan dan tulis, reseptif dan produktif dalam segala aspek komunikatifnya (linguistik, wacana, sosiolinguistik, dan strategis).

Khusus dalam pembelajaran bahasa Inggris untuk anak-anak, seorang 
guru juga dituntut untuk memiliki pengetahuan tentang penggunaan bahasa Inggris di kelas, menerapkan teknikteknik tertentu dalam proses pembelajaran, dan tahu bagaimana menfasilitasi proses pembelajaran anak dengan cara yang lebih menyenangkan sebagaimana

\section{Kelompok Kerja Guru (KKG)}

\section{Pengertian KKG}

Menurut Standar Pengembangan Kelompok Kerja Guru (KKG) Musyawarah Guru Mata Pelajaran (MGMP) Direktorat Profesi Pendidik Direktorat Jenderal Peningkatan Mutu Pendidik Dan Tenaga Kependidikan Departemen Pendidikan Nasional Republik Indonesia Tahun 2008, Bab II, tentang Ketentuan Umum, KKG (Kelompok Kerja Guru) merupakan wadah atau forum kegiatan profesional bagi para guru Sekolah Dasar/Madrasah Ibtidaiyah di tingkat gugus atau kecamatan yang terdiri dari beberapa guru dari beberapa sekolah.

\section{Tujuan KKG}

Tujuan dibentuknya Kelompok Kerja Guru (KKG) adalah sebagai berikut:

1. Memperluas wawasan dan pengetahuan guru dalam berbagai hal, khususnya penguasaan substansi materi pembelajaran, penyusunan silabus, penyusunan bahan-bahan pembelajaran, strategi pembelajaran, metode pembelajaran, memaksimalkan pemakaian sarana/prasarana belajar, memanfaatkan sumber belajar, dsb.

2. Memberi kesempatan kepada anggota kelompok kerja atau musyawarah kerja untuk berbagi pengalaman serta saling memberikan bantuan dan umpan balik.

3. Meningkatkan pengetahuan dan keterampilan, serta mengadopsi pendekatan pembaharuan dalam pembelajaran yang lebih professional bagi peserta kelompok kerja atau musyawarah kerja.

4. Memberdayakan dan membantu anggota kelompok kerja dalam melaksanakan tugas-tugas pembelajaran di sekolah.

5. Mengubah budaya kerja anggota kelompok kerja atau musyawarah kerja (meningkatkan pengetahuan, kompetensi dan kinerja) dan mengembangkan profesionalisme guru melalui kegiatan-kegiatan pengembangan profesionalisme di tingkat KKG/MGMP.

6. Meningkatkan mutu proses pendidikan dan pembelajaran yang tercermin dari peningkatan hasil belajar peserta didik.

7. Meningkatkan kompetensi guru melalui kegiatan-kegiatan di tingkat KKG/MGMP.

\section{Program KKG}

Bab III tentang Standar Pengembangan KKG/MGMP (2008:7), menegaskan bahwa program KKG/MGMP terdiri dari program rutin dan program pengembangan. Program rutin sekurangkurangnya terdiri dari: a) Diskusi permasalahan pembelajaran, b) Penyusunan silabus, program semester, dan Rencana Program Pembelajaran, c) Analisis kurikulum, d) Penyusunan instrumen evaluasi pembelajaran, e) Pembahasan materi dan pemantapan menghadapi Ujian Nasional. Sedangkan program pengembangan dapat dipilih sekurangkurangnya tiga dari kegiatan-kegiatan berikut: a) Penelitian, b) Penulisan Karya Tulis Ilmiah, c) Seminar, lokakarya, koloqium (paparan hasil penelitian), dan diskusi panel, d) Pendidikan dan Pelatihan berjenjang (diklat berjenjang), e) Penerbitan jurnal KKG/ MGMP, f) Penyusunan website KKG/ MGMP, g) Forum KKG/MGMP provinsi, h) Kompetisi kinerja guru, i) Peer Coaching (Pelatihan sesama guru menggunakan media ICT), j) Lesson 
Study (kerjasama antar guru untuk memecahkan masalah pembelajaran), k) Professional Learning Community (komunitas-belajar professional)

\section{METODOLOGI PENELITIAN}

\section{Jenis Penelitian}

Penelitian ini menggunakan metode penelitian tindakan partisipatif (Participatory Action Research). Menurut Kemmis dan McTaggart (1988) salah satu tujuan yang ingin dicapai dalam Penelitian Tindakan ini adalah memperbaiki kondisi kelas yang ada atau meningkatan kualitas berkaitan dengan masalah-masalah pendidikan. Jenis penelitian ini dipilih untuk meningkatkan kompetensi pengelolaan pembelajaran bahasa Inggris di sekolah dasar melalui kegiatan KKG. Secara lebih khusus, penelitian ini menggunakan siklus yang dimulai dengan perencanaan, pelaksanaan, evaluasi dan refleksi yang akan dijadikan acuan kembali untuk memperbaiki perencanaan untuk pembelajaran berikutnya.

\section{Setting Penelitian}

Penelitian ini dilakukan pada Kelompok Kerja Guru (KKG) mata pelajaran bahasa Inggris Sekolah Dasar di kecamatan Lima Kaum kabupaten Tanah Datar.

Subyek penelitian ini adalah seluruh guru mata pelajaran bahasa Inggris di kecamatan Lima Kaum Batusangkar yang berjumlah 19 orang. Pemilihan subyek ini didasarkan atas tanggung jawab professional sebagai dosen pengajar bahasa Inggris dan pengampu mata kuliah English for Children atas fenomena yang terjadi, khususnya dalam pembinaan, pengembangan wawasan dan keterampilan guru mata pelajaran bahasa Inggris di Sekolah Dasar di kecamatan Lima Kaum kabupaten Tanah Datar.

\section{Teknik dan Alat Pengumpul Data}

Dalam penelitian ini peneliti merupakan instrumen kunci. Dalam melaksanakan tugasnya, peneliti dibantu dengan beberapa alat pengumpul data antara lain: (1) jurnal dan catatan lapangan peneliti, (2) pedoman wawancara, (3) kuesioner, dan (4) lembaran observasi. Seluruh aktivitas dan respon yang terjadi selama proses penelitian berlangsung dicatat untuk dijadikan sebagai bahan wawancara dan diskusi dengan guru.

\section{Langkah-langkah Penelitian}

Penelitian tindakan partisipatif ini pada dasarnya mengadopsi pola dan tahapan penelitian tindakan (action research) pada umumnya. Dalam penelitian tindakan partisipatif (PAR) ini mengikuti tahapan sebagai berikut: 1) refleksi awal, 2) perencanaan, 3) pelaksanaan dan 4) pemantauan serta refleksi. Secara rinci, tahapan di atas dijelaskan sebagai berikut:

\section{Refleksi awal}

Dalam tahapan ini, kegiatan yang akan dilakukan adalah: a) Mengidentifikasi masalah dan b) Memilih dan memilah masalah

a) Perencanaan.

Dalam tahapan ini, kegiatan yang akan dilakukan adalah: 1) Merumuskan masalah, 2) Menetapkan rancangan tindakan, dan 3) Menyusun jadwal kegiatan. Menetapkan rancangan tindakan (poin 2), yang meliputi: a) Menyusun rancangan kegiatan pelatihan yang berkaitan dengan Komponen Kompetensi Pengelolaan Pembelajaran dan Wawasan Kependidikan, khususnya Sub Komponen Kompetensi Pengelolaan Pembelajaran yang meliputi: Menyusun rencana pembelajaran, Melaksanakan pembelajaran, Menilai prestasi belajar peserta didik, dan Melaksanakan tindak lanjut hasil 
penilaian prestasi belajar peserta didik. b) Menyiapkan alat bantu penelitian: format observasi, angket dan panduan wawancara, dan c) Menyusun rencana pengolahan data.

b) Pelaksanaan tindakan dan pengamatan

a. Melaksanakan kegiatan Pelatihan, yaitu 1) Menyusun rencana pembelajaran, 2) Melaksanakan pembelajaran, 3) Menilai prestasi belajar peserta didik, dan 4) Melaksanakan tindak lanjut hasil penilaian prestasi belajar peserta didik.

b. Melakukan pengamatan dan wawancara dengan subyek penelitian tentang pemahaman mereka terhadap materi pelatihan dan dampaknya terhadap peningkatan kompetensi mereka terhadap materi yang disajikan.

c) Refleksi

Dalam tahapan ini akan diperoleh gambaran sejauh mana indikator peningkatan kompetensi telah dicapai dan seberapa efektif pelatihan dan penugasan yang telah diberikan. Dalam tahapan ini, kegiatan yang akan dilakukan adalah: a) analsis sistematis, b) pemaknaan, c) penjelasan, d) penyimpulan data dari informasi yang dikumpulkan, dan e) perumusan perencanaan dan tindakan yang perlu dilakukan selanjutnya.

Analisis yang digunakan dalam penelitian ini adalah memanfaatkan analisa deskriptif dari proses dan hasil pelatihan dan penugasan. Analisis juga dilakukan dari hasil observasi dan wawancara. Analisis berdasarkan siklus yang secara bertahap. Analisis 1 dalam siklus 1 yang hasilnya direfleksikan ke siklus 2 begitu juga ke siklus 3. Sedangkan refleksi yang dilakukan sesuai dengan perencanaan yang dilakukan.

\section{Teknik Analisis Data}

Teknik analisis data yang digunakan dalam penelitian ini adalah dengan mengacu kepada prinsip penelitian tindakan yang bersifat kualitatif. Dalam hal ini, pekerjaan menganalisis tidak dapat dilepaskan dari tindakan dan pengamatan. Analisis data tergantung kepada apa yang ditemukan selama tindakan dan pengamatan dilakukan. Kerangka teknik analisis data dibuat ketika peneliti melihat proses tindakan. Analisis berjalan selama tindakan dan pengamatan berlangsung.

\section{HASIL PENELITIAN DAN PEMBAHASAN}

\section{Hasil Penelitian}

\section{Pendahuluan}

Bagian ini menguraikan hal-hal yang berkaitan dengan penelitian, yang meliputi tahapan persiapan dan pelaksanaan. Tahapan persiapan pada dasarnya menciptakan kondisi sehingga kegiatan Kelompok Kerja Guru (KKG) yang merupakan medium utama yang berkaitan langsung dengan kegiatan penelitian ini dapat dilaksanakan. Sedangkan tahapan pelaksanaan adalah rangkaian kegiatan utama yang dilaksanakan dalam rangka mencapai tujuan penelitian ini.

Kegiatan persiapan ini dilaksanakan pada awal bulan Juni 2011 sedangkan pelaksanaan kegiatan dilaksanakan pada bulan minggu ketiga Juni 2011 hingga Minggu ke empat Oktober. Secara rinci kedua tahapan ini dapat dijelaskan sebagai berikut:

1) Persiapan

Untuk memastikan agar pelaksanaan kegiatan penelitian ini berjalan sesuai dengan apa yang direncanakan, beberapa persiapan yang telah dilakukan dapat dideskripsikan sebagai beikut: 
a. Melakukan koordinasi dengan koordinator Kelompok Kerja Guru (KKG) bahasa Inggris kecamatan Lima Kaum Batusangkar, terutama dalam hal mengkoordinir guruguru bahasa Inggris Sekolah Dasar yang tergabung dalam wadah $\mathrm{KKG}$ tersebut. Koordinasi ini telah dilakukan semenjak bulan Juni 2011. Dalam hal ini, peneliti dan koordinator bersepakat untuk berkolaborasi dalam rangka peningkatan kompetensi guru-guru bahasa Inggris yang tergabung ke dalam KKG kecamatan Lima Kaum.

b. Melakukan koordinasi dengan Musyawarah Kerja Kepala Sekolah (MKKS) SD di kecamatan Lima Kaum melalui Koordinator KKG. Koordinasi dimaksudkan untuk meminta bantuan moril dari kepala sekolah kepada guru bahasa Inggris di sekolah mereka dalam bentuk izin untuk mengikuti kegiatan peningkatan. Koordinasi ini telah dilakukan oleh koordinator KKG.

c. Melakukan koordinasi dengan Unit Pelaksana Teknis Daerah kecamatan Lima Kaum untuk memfasilitasi kegiatan ini yang dilakukan oleh Koordinator KKG.

d. Menginformasikan kepada guruguru bahasa Inggris Sekolah Dasar yang tergabung dalam wadah KKG kecamatan Lima Kaum tentang kegiatan peningkatan kompetensi pengelolaan pembelajaran bahasa Inggris di Sekolah Dasar oleh koordinator KKG.

e. Menyiapkan instrumen yang akan digunakan untuk mengukur sejauh mana peningkatan kompetensi pengelolaan pembelajaran bahasa Inggris di Sekolah Dasar oleh guru-guru bahasa Inggris Sekolah Dasar yang tergabung dalam wadah KKG tersebut, khususnya yang berkaitan dengan aspek persiapan pembelajaran, yaitu penyusunan silabus dan Rencana Pelaksanaan Pembelajaran.

f. Menyiapkan presentasi yang berkaitan dengan model penyusunan silabus, pengembangan RPP, dan aplikasinya dalam pembelajaran di kelas.

g. Menginformasikan kepada guruguru melalui Kordinator KKG untuk menyerahkan silabus dan RPP yang mereka rancang untuk dibahas bersama-sama di dalam kelas.

\section{Pelaksanaaan}

Penelitian ini dilaksanakan dalam dua tahap. Tahap pertama berkaitan dengan peningkatan kompetensi guru dalam menyusun silabus. Sedangkan tahap kedua berkaitan dengan peningkatan kompetensi guru dalam menyusun RPP. Masing-masing tahap terdiri dari beberapa siklus yang terdiri dari kegiatan yang meliputi: perencanaan, pelaksanaan, pengamatan, dan refleksi, jumlahnya sangat tergantung kepada peningkatan kompetensi yang dicapai oleh guru tersebut. Tahap pertama terdiri dari empat siklus yang difokuskan kepada peningkatan kompetensi pembelajaran dalam menyusun silabus dan tahap kedua yang terdiri dari dua siklus yang difokuskan kepada peningkatan kompetensi pembelajaran dalam menyusun RPP. Dengan demikian, ada dua tahapan yang terdiri dari enam siklus yang berlangsung dari 23 Juni 2011 hingga 13 Oktober 2011 dimulai jam 9 pagi bertempat di Aula SDN 01 Balai Batu dan Ruang Pertemuan UPTD Dinas Pendidikan kecamatan Lima Kaum kabupaten Tanah Datar.

\section{Pembahasan}

Sebagaimana telah diungkapkan sebelumnya bahwa penelitian ini 
bertujuan untuk meningkatkan kompetensi pengelolaan kelas guru bahasa Inggris Sekolah Dasar di kecamatan Lima Kaum melalui kegiatan Kelompok Kerja Guru (KKG) khususnya dalam pengembangan silabus dan RPP. Penelitian yang dilakukan dalam bentuk kegiatan KKG ini memberikan gambaran akan rendahnya pemahaman mereka terhadap pembelajaran bahasa Inggris di Sekolah Dasar. Ini dilihat dari persiapan perangkat pembelajaran mereka yang tidak maksimal. Masih ditemukan bahwa dalam mengajar mereka tidak mempersiapkan secara maksimal perangkat pembelajaran, terutama silabus dan RPP. Ini dapat dilihat dari 'keseragaman' silabus dan RPP yang mereka pahami. Ada sebuah pemahaman yang keliru bahwa KKG merupakan sarana untuk 'menyeragamkan' perangkat pembelajaran mereka sehingga hanya personil tertentu saja yang merancang dan selanjutnya diperbanyak sesuai dengan kebutuhan. Itupun, masih ditemukan rancangan silabus yang yang tidak sesuai dengan Standar Proses.

Kegiatan Kelompok Kerja Guru (KKG) dalam penelitian ini telah memberikan pemahaman yang lebih proporsional kepada guru-guru bahasa Inggris di kecamatan Lima Kaum tentang kompetensi pembelajaran yang harus mereka kuasai meskipun mereka memiliki latar belakang keilmuan yang berbeda. Peningkatan ini dapat dilihat dari pemahaman mereka hakikat pembelajaran bahasa Inggris untuk siswa anak-anak dan implementasinya dalam pembelajaran bahasa Inggris untuk siswa Sekolah Dasar. Selanjutnya, peningkatan pemahaman mereka akan hakikat silabus dan RPP juga dapat diamati melalui perubahan paradigma penyusunan silabus dan RPP dari 'kesamaan silabus dan RPP' untuk semua guru bahasa Inggris di kecamatan Limakaum ke arah 'kesamaan persepsi' dalam pengem- bangan silabus dan RPP. Hasil pengamatan selama kegiatan berlangsung, baik dalam persiapan pembelajaran yang telah dilakukan oleh guru-guru maupun presentasi, tanggapan, pertanyaan dan saran yang mereka berikan dalam setiap pertemuan telah memberikan gambaran terhadap peningkatan pemahaman mereka terhadap pengembangan kedua komponen pembelajaran di atas.

\section{PENUTUP}

Mengacu kepada rumusan masalah dan temuan penelitian, dapat disimpulkan bahwa kegiatan Kelompok Kerja Guru (KKG) telah dapat meningkatkan kompetensi pengelolaan pembelajaran guru bahasa Inggris di Sekolah Dasar di kecamatan Lima Kaum kabupaten Tanah Datar dalam menyusun rencana pembelajaran.

Secara lebih rinci, temuan penelitian juga menunjukkan bahwa 1) kegiatan Kelompok Kerja Guru (KKG) telah meningkatkan kompetensi pengelolaan pembelajaran guru bahasa Inggris di sekolah dasar di kecamatan Lima Kaum kabupaten Tanah Datar dalam menyusun silabus, dan 2) kegiatan Kelompok Kerja Guru (KKG) telah meningkatkan kompetensi pengelolaan pembelajaran guru bahasa Inggris di Sekolah Dasar di kecamatan Lima Kaum kabupaten Tanah Datar dalam menyusun rencana pelaksanaan pembelajaran (RPP).

Mengacu kepada kesimpulan di atas, kegiatan-kegiatan Kelompok Kerja Guru (KKG) telah meningkatkan kompetensi pengelolaan pembelajaran guru bahasa Inggris di Sekolah Dasar di kecamatan Lima Kaum Kabupaten Tanah Datar perlu dikembangkan lagi kompetensi lainnya yaitu melaksanakan pembelajaran, menilai menilai prestasi belajar peserta didik dan melaksanakan tindak lanjut hasil penilaian prestasi belajar peserta didik untuk mendapatkan 
gambaran dan hasil yang maksimal tentang kompetensi pengelolaan pembelajaran guru bahasa Inggris di Sekolah

\section{DAFTAR RUJUKAN}

Cameron, Lynne. 2001. Teaching Languages to Young Learners. Cambridge: Cambridge University Press.

Harmer, Jeremy. 2002. English Language Teaching. Cambridge: Campridge University Press.

Kasihani K. E. Suyanto. 2001. Improving a Course Design through Classroom Action Research. Jurnal Ilmu Pendidikan. Malang: Universitas Negeri Malang.

Kemmis, S and R. McTaggart. 1988. The Action Research Planner. Geelong: Deakin University Press.

Lampiran Peraturan Menteri Pendidikan Nasional Nomor 16 Tahun 2007 tentang Standar Kualifikasi Akademik dan Kompetensi Guru

Menteri Pendidikan dan Kebudayaan. Surat Keputusan No. 0487/4/1992

Pufahl, Ingrid, Nancy R. Rhodes, and Donna Christian. 2001. What We can Learn from Foreign Language
Dasar di kecamatan Limakaum kabupaten Tanah Datar.

Program. ERIC Digest. September 2001.

Rosenbusch, Marcia. 2000. Guidelines for Starting an Elementary School Foreign Language Program. ERIC Digest. September 2000.

Standar Kompetensi Guru, Bagian Komponen Pengelolaan Pembelajaran Dan Wawasan Kependidikan dan Komponen Pengembangan Profesi (2010), tersedia dalam http://www.geocities.com/pengem bangan_sekolah/standarguru.html Diakses 10 September 2010.

Ur, Penny. 2001. A Course in Language Teaching: Practice and Theory. Cambridge: Cambridge University Press.

Lampiran Peraturan Menteri Pendidikan Nasional Nomor 41 Tahun 2007 Tanggal 23 November 2007 Tentang Standar Proses Untuk Satuan Pendidikan Dasar Dan Menengah. 